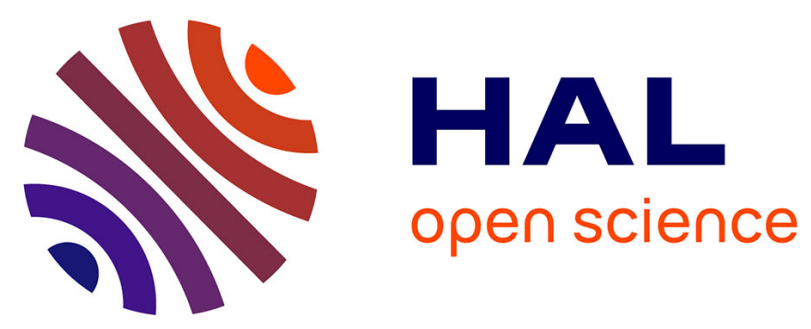

\title{
Prioritizing Knowledge Transfer Conditions for Innovation Ecosystems: A Mixed-Method Approach
} Emily Bacon, Michael Williams, Gareth Davies

\section{To cite this version:}

Emily Bacon, Michael Williams, Gareth Davies. Prioritizing Knowledge Transfer Conditions for Innovation Ecosystems: A Mixed-Method Approach. 18th Conference on e-Business, e-Services and e-Society (I3E), Sep 2019, Trondheim, Norway. pp.747-758, 10.1007/978-3-030-29374-1_61 . hal02510151

\section{HAL Id: hal-02510151 \\ https://hal.inria.fr/hal-02510151}

Submitted on 17 Mar 2020

HAL is a multi-disciplinary open access archive for the deposit and dissemination of scientific research documents, whether they are published or not. The documents may come from teaching and research institutions in France or abroad, or from public or private research centers.
L'archive ouverte pluridisciplinaire HAL, est destinée au dépôt et à la diffusion de documents scientifiques de niveau recherche, publiés ou non, émanant des établissements d'enseignement et de recherche français ou étrangers, des laboratoires publics ou privés. 


\title{
Prioritizing knowledge transfer conditions for innovation ecosystems: A mixed-method approach
}

\author{
Emily Bacon ${ }^{1}{ }^{[0000-0001-9933-3902]}$ Michael Williams ${ }^{1}{ }^{\text {[0000-0002-3047-0332] }}$ and Gareth Davies ${ }^{1}$ \\ [0000-0001-7872-7574] \\ ${ }^{1}$ School of Management, Swansea University, Bay Campus, Swansea, SA1 8EN
$\{950171$, m.d.williams, g.h.davies $\}$ @swansea.ac.uk
}

\begin{abstract}
Open innovation ecosystems rely upon inter-organisational knowledge transfer to support co-creation. Despite the significance of this process, and an abundance of open innovation research, empirical investigation and discussion of diverse knowledge transfer conditions across open innovation ecosystems remains unaddressed within existing literature. Using a mixed-method approach, this study investigates how knowledge, firm, and partner-relationship characteristics affect the successful exchange of knowledge between ecosystem partners. Interpretive Structural Modelling was employed to ascertain expert opinions regarding the interrelations between the transfer conditions. The combinatory nature of these conditions, and their integration into solutions for success, was further explored utilizing fuzzy-set Qualitative Comparative Analysis. Results indicate that conditions for knowledge transfer success are highly interrelated and co-dependent. Limitations and implications are discussed.
\end{abstract}

Keywords: Open innovation, ecosystem, knowledge transfer, fsQCA, ISM

\section{Introduction}

The rapid evolution of today's business environment necessitates the acquisition and integration of diverse, novel capabilities, generated through ecosystem engagement [1]. Innovation ecosystems engage multiple organisational actors to collaborate across a range of industries, coevolving their capabilities for innovative purposes [2] which relies upon inter-organisational knowledge transfer [3]. Despite the significance of this process, limited research has prioritized the conditions for knowledge transfer between ecosystem partners. Bacon, Williams and Davies [4] utilize fuzzy-set Qualitative Comparative Analysis (fsQCA) to analyze knowledge transfer conditions for open innovation but fail to concretely ascertain their importance. Innovation-related outcomes have been analyzed by other scholars utilizing fsQCA [5] as well as additional novel techniques such as Interpretive Structural Modelling (ISM) [6]. Existing literature reveals that individual-level analyses remain unexplored [7]: moreover, Ritala, Kraus and Bouncken [8] call for the application of more novel techniques for ecosystem analyses. Against this backdrop, this research aims to assess ecosystem partner perceptions of the extent to which combinations of conditions are responsible for knowledge transfer success, in the context of innovation ecosystems. A mixed-method approach will be utilized to investigate two research questions: firstly, do specific conditions carry greater 
prominence when transferring knowledge successfully? This will be determined through ISM. Secondly, are there multiple solutions for knowledge transfer success? Using the principles of complexity theory, this will be investigated through fsQCA.

The remainder of this paper is structured as follows. Section 2 explores current research surrounding knowledge transfer within innovation ecosystems. Section 3 presents the conditions applied within this research based upon a review of existing interorganisational knowledge transfer literature. Section 4 identifies the sample and methods and explicates the chosen analytical techniques. Sections 5 and 6 demonstrate the main results arising from ISM and fsQCA respectively. Section 7 discusses these results; Section 8 concludes this paper.

\section{Existing Literature}

Open innovation [9] comprises a paradigm that supersedes traditional in-silo ideation, with organisations transferring knowledge across their organisational boundaries. Approaches to open innovation evidence its facilitation by a greater openness towards external knowledge sources [10]. Involving the movement of knowledge between actors, effective knowledge transfer is argued to be critical for innovation [11].

Extant research denotes that the increasingly complex nature of knowledge necessitates multiple partnerships with organisations who can deliver on distinct innovative requirements [11]. Knowledge is argued to transfer more readily between organisations who construct a solid inter-organisational network [12]. In the context of open innovation, ecosystems constitute an evolution of the inter-organisational network principle, and encompass a key resource for extrapolating external knowledge. Innovation ecosystems are comprised of multiple organisational actors, who collaborate within cooperative and competitive environments to generate new products and support innovative developments [2]. Ecosystem partnerships thus develop so that organisations may share ideas [3] expediting the open innovation process through enabling firms to access highquality, relevant knowledge from multiple sources.

Despite increasing research activity surrounding inter-organisational knowledge transfer for open innovation in the context of ecosystem-level analyses [13-14] significant gaps remain. Holistic examinations of successful knowledge transfer within an ecosystem context are necessary [7] to potentially explicate the high failure rate of innovation partnerships: empirical examinations of factor interdependencies could address this detriment [7]. Determinants of inter-organisational knowledge transfer success remain well researched [15-16] but hierarchical associations between constituents within ecosystem contexts are unexplored. What is absent from extant research is a directed focus toward the significance of knowledge transfer success, and importance of its determinants, in the context of open innovation ecosystems. Recent reviews of open innovation literature $[14,17]$ further emphasize that this area remains under-researched: this research addresses this gap. 


\section{Conceptual Outline}

Based on a review of sixty-four articles examining factors for inter-organisational knowledge transfer [4], three predominant groupings arose from the most common conditions: knowledge, relationship, and firm-related. Due to existing research proposing many definitions of knowledge transfer success, with no generally accepted definition, this research outlines successful knowledge transfer to involve the 'resourceful exchange of knowledge between organisations, involving measurable and effective knowledge absorption, application and satisfaction by the recipient organisation', in line with Bacon et al. [4].

\subsection{Knowledge Characteristics}

The nature of the knowledge exchanged between organisations can affect ease of transfer. Explicit knowledge, retaining more information-based qualities, arguably transfers more readily than tacit knowledge, which purports more personal attributes grounded upon individual experiences [18]. Explicit knowledge is designated as more translatable due to greater ease in articulation [18]: thus, the type of knowledge exchanged between organisations can impact the overall transfer process. Furthermore, the ability of the recipient organisation to understand the knowledge exchanged further facilitates transfer [15]. The degree of understanding possessed by the recipient organisation is mediated by the ambiguity of the knowledge itself [19]. This causal ambiguity perpetuates a lack of clarity surrounding the underlying origins and components of knowledge [20] which impedes the transfer process. Thus, knowledge-related conditions for transfer success include knowledge type, the degree of understanding possessed by the recipient organisation, and low causal ambiguity.

\subsection{Relationship Characteristics}

Existing literature suggests that characteristics of inter-organisational partnerships contribute to knowledge transfer success. Trustworthy partnerships arguably motivate organisations to collaborate and exchange information [21]. Trust refers to a positive expectation that partners will execute their obligations as a knowledge transferee and will reliably source the relevant information [21]. Further research [18] argues that trust strengthens a partnership. Relatedly, the strength of inter-organisational ties further affects the transfer process [10]. Strong ties encourage organisations to share detailed and complex knowledge, and correlate with increased knowledge exchange [16]. Trust and tie strength formulate the relationship characteristics category.

\subsection{Organisational Characteristics}

Recipient organisation characteristics further affect knowledge transfer success. Similarities between organisational cultures, in terms of shared beliefs, values and practices arguably enable knowledge transfer [10]. In order to learn from a partner, however, 
organisations must propagate an intent to do so. Learning intent acts as a driving force for pursuing inter-organisational partnerships, increasing knowledge transfer [19]. However, enthusiasm surrounding knowledge acquisition requires support to enable its absorption by the recipient firm. This final characteristic - absorptive capacity [22] encompasses an organisational ability to recognize potential knowledge value, diffuse it internally, and utilize it beneficially, which in turn encourages knowledge transfer across organisational boundaries [15]. Hence, cultural similarity, learning intent, and absorptive capacity formulate organisational conditions for knowledge transfer.

\subsection{Combinations of Conditions}

Aside from the eight most prevalent conditions, many other factors were cited within existing research: this reinforces that no single condition can be identified as responsible for knowledge transfer success. Pappas [23] states that multiple and equally effective configurations of causal conditions can exist for a given outcome. In line with complexity theory, this research proposes that there is no single, optimum configuration that best represents knowledge transfer success: the construct cannot be reduced to a singular model of best-fit. The knowledge transfer conditions are expected possess equal importance.

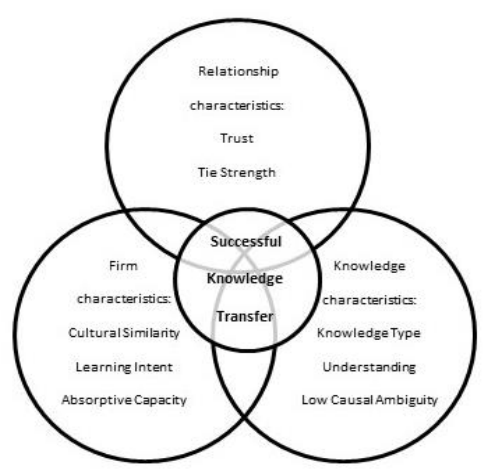

Fig. 1. Conceptual Model

\section{Research Method}

\subsection{Sample}

This research adopts a mixed-method approach. During the first phase of data collection, a questionnaire was distributed to eleven key stakeholders, deemed experts in ecosystem engagement. Participants were sourced from a multinational keystone organisation, and included partner management coordinators, alliance managers, and strategic partnership managers. The majority of participants possessed over seven years of experience. The questionnaire extracted their opinions of the relationships between the 
transfer conditions. Each question was used to ascertain the pairwise relationship between the conditions, requiring participants to select from four options: (1) condition 1 influenced condition 2, (2) condition 2 influenced condition 1, (3) the conditions influenced each other, or (4) the conditions possessed no relationship. These questions were used to assess each of the pairwise relations, resulting in a total of thirty-four questions.

The second phase of data collection involved semi-structured telephone interviews, using a multi-industry sample of twenty ecosystem partners from a range of organisations, differing in size and scale. All organisations were engaged in inter-organisational partnerships within open innovation ecosystems and were sourced through purposive sampling. Participants were required to assess the presence of each condition within their ecosystem partnership on a seven-point semantic differential [24] scale. Additional unstructured questions supplemented the scales to present participants with the opportunity to offer further insights into their ratings. Knowledge transfer success was also measured using five-point semantic differential scales to assess the five separate components of the definition of transfer success - resourcefulness of transfer, measurable outcomes, effective absorption, effective application, and satisfaction.

\subsection{Analytical Tools}

The aim of the first phase of data analysis was to detect the interrelations between conditions, whilst pinpointing their hierarchical significance: ISM [25] was employed to achieve this. An interactive and interpretive method, ISM relies upon expert consensus to ascertain how variables are related. Within existing literature, expert opinions are often sought through questionnaires [26-27]. ISM alleviates complexity through decomposing a given system into several elements, using this to generate a structural model and visual hierarchy of the conditions representing the system structure [28]. In this manner, ISM prioritizes and improves understanding of the key relationships between the conditions [28] which proved particularly fruitful in this context.

The second phase necessitated an analysis that would illuminate how the transfer conditions contributed to knowledge transfer success. FsQCA purports that a given combination of causal conditions can represent one of several paths to an outcome [29]. It enables the comparison of multiple cases, whilst capturing their diversity and complexity. FsQCA comprises a configurational approach, where individual cases are viewed as compositions of interrelated components [30]. FsQCA possesses particular suitability for this research due to its systematic comparisons of cases within a small-N sample [30]. The notion of equifinality, an underlying tenet of fsQCA, further elucidates its application, in that multiple configurations are expected for the outcome. Additionally, the notion of causal asymmetry, where conditions leading to the presence of an outcome differ from those leading to its absence, evidences the suitability of fsQCA for exploring the expectedly causally asymmetrical notion of success.

\subsection{Stages in ISM}

The application of ISM within any research context is comprised of a series of stages [28]. Firstly, the variables to be investigated are identified. The type of relationship 
between these variables is selected: in this study, a contextual relationship of 'influences' was chosen. Participants are asked to use their expertise to decide upon the pairwise relationships between the variables. Four notations indicate the direction of the relationship between two exemplary factors, $\mathrm{i}$ and $\mathrm{j}: \mathrm{V}=\mathrm{i}$ influences $\mathrm{j} ; \mathrm{A}=\mathrm{j}$ influences $\mathrm{i} ; \mathrm{X}=\mathrm{i}$ and $\mathrm{j}$ influence each other; $\mathrm{O}=$ no relationship. These VAXO notations are represented within a structural self-interaction matrix. The pairwise relations are then converted into $1 \mathrm{~s}$ and 0 s within a reachability matrix, based upon the following logic. If the $(i, j)$ entry is $V$, then the $(i, j)$ entry in the reachability matrix becomes 1 , and the $(\mathrm{j}, \mathrm{i})$ entry becomes 0 . If the $(\mathrm{i}, \mathrm{j})$ entry is $\mathrm{A}$, then the $(\mathrm{i}, \mathrm{j})$ entry in the reachability matrix becomes 0 and the $(\mathrm{j}, \mathrm{i})$ entry becomes 1 . If the $(\mathrm{i}, \mathrm{j})$ entry is $\mathrm{X}$, then the $(\mathrm{i}, \mathrm{j})$ and $(\mathrm{j}, \mathrm{i})$ entries in the reachability matrix both become 1 . If the $(i, j)$ entry is $O$, then the $(i, j)$ and $(\mathrm{j}, \mathrm{i})$ entries in the reachability matrix both become 0 . The reachability matrix then requires further refinement based upon transitivity, which states that if $\mathrm{A}$ is related to $\mathrm{B}$ and $\mathrm{B}$ is related to $\mathrm{C}$, then $\mathrm{A}$ and $\mathrm{C}$ are related. Transitivity alters the entries for variables which are indirectly related, resulting in a final reachability matrix, which displays the driving and dependence power of the variables. This produces a final digraph.

\subsection{Stages in FsQCA}

FsQCA requires that data be calibrated into fuzzy sets, which encompass variables that are continuous in nature: they can retain degrees of membership within a set. In this study, the type of knowledge transferred was split into tacit and explicit knowledge, and assigned three-value fuzzy set memberships of 1, 0.5, and 0 . All other conditions were assigned seven-value fuzzy set memberships. In line with Ordanini et al. [31], the semantic differential scales were used to outline membership values: full membership was fixed at 6 , the crossover point was set at 4.5 , and non-membership was fixed at 3 .

To calibrate the outcome, participant responses to outcome scales were averaged, and applied as baseline values. If participants had responded with a score higher than the average, their response was re-coded as 1; if it was lower, 0. Applying this principle across the five statements, these scores were then re-averaged for each participant, and used as the fuzzy-set values for outcome membership. Scores of above 0.8 constituted full-membership; 0.5 was a crossover point; and 0.2 was outlined as non-membership.

Following the calibration procedure, fsQCA produces a truth table, containing all logically possible combinations of cases. Cases with consistency values of less than 0.8 and frequency values of less than 1 [30] were removed from the analysis.

\section{$5 \quad$ ISM Results}

Based upon the expert opinions, the Structural Self-Interaction Matrix (SSIM) was developed utilizing the VAXO notations (Table 1). 
Table 1. Structural Self-Interaction Matrix

\begin{tabular}{|c|c|c|c|c|c|c|c|c|}
\hline & $\begin{array}{l}\text { Knowledge } \\
\text { Type }\end{array}$ & $\begin{array}{l}\text { Understand- } \\
\text { ing }\end{array}$ & $\begin{array}{l}\text { Causal } \\
\text { Ambigu- } \\
\text { ity }\end{array}$ & Trust & $\begin{array}{l}\text { Tie } \\
\text { Strength }\end{array}$ & $\begin{array}{l}\text { Cultural } \\
\text { Similarity }\end{array}$ & $\begin{array}{l}\text { Learn- } \\
\text { ing } \\
\text { Intent } \\
\end{array}$ & $\begin{array}{l}\text { Absorp- } \\
\text { tive } \\
\text { Capacity }\end{array}$ \\
\hline \multicolumn{9}{|l|}{$\begin{array}{l}\text { Knowledge } \\
\text { Type }\end{array}$} \\
\hline $\begin{array}{l}\text { Understand- } \\
\text { ing }\end{array}$ & $\mathrm{X}$ & & & & & & & \\
\hline $\begin{array}{l}\text { Causal Am- } \\
\text { biguity }\end{array}$ & V & $\mathrm{X}$ & & & & & & \\
\hline Trust & $\mathrm{V}$ & $\mathrm{X}$ & $\mathrm{X}$ & & & & & \\
\hline Tie Strength & $X$ & $\mathrm{O}$ & $\mathrm{X}$ & $X$ & & & & \\
\hline $\begin{array}{l}\text { Cultural } \\
\text { Similarity } \\
\end{array}$ & $\mathrm{X}$ & $\mathrm{X}$ & $\mathrm{X}$ & V & V & & & \\
\hline $\begin{array}{l}\text { Learning In- } \\
\text { tent }\end{array}$ & $\mathrm{X}$ & $X$ & $\mathrm{X}$ & $\mathrm{O}$ & A & X & & \\
\hline $\begin{array}{l}\text { Absorptive } \\
\text { Capacity }\end{array}$ & $\mathrm{X}$ & $\mathrm{X}$ & $\mathrm{X}$ & $\mathrm{X}$ & $\mathrm{X}$ & $\mathrm{X}$ & $\mathrm{X}$ & \\
\hline
\end{tabular}

The SSIM matrix was converted into the Initial Reachability Matrix (IRM) by converting the scores into 1s and 0s (see Section 4.3). It has been excluded here due to space limitations. The IRM was further refined based upon transitivity to obtain the Final Reachability Matrix (Table 2): all 0 values were converted to 1.

Table 2. Final Reachability Matrix

\begin{tabular}{|l|l|l|l|l|l|l|l|l|l|}
\hline & $\begin{array}{l}\text { Knowle } \\
\text { gge } \\
\text { Type }\end{array}$ & $\begin{array}{l}\text { Under- } \\
\text { stand- } \\
\text { ing }\end{array}$ & $\begin{array}{l}\text { Causal } \\
\text { Ambi- } \\
\text { guity }\end{array}$ & Trust & $\begin{array}{l}\text { Tie } \\
\text { Strength }\end{array}$ & $\begin{array}{l}\text { Cultural } \\
\text { Similar- } \\
\text { ity }\end{array}$ & $\begin{array}{l}\text { Learn- } \\
\text { ing } \\
\text { Intent }\end{array}$ & $\begin{array}{l}\text { Absorp- } \\
\text { tive } \\
\text { Capacity }\end{array}$ & $\begin{array}{l}\text { Depend- } \\
\text { ence } \\
\text { power }\end{array}$ \\
\hline $\begin{array}{l}\text { Knowledge } \\
\text { Type }\end{array}$ & 1 & 1 & $1 *$ & $1^{*}$ & 1 & 1 & 1 & 1 & 8 \\
\hline $\begin{array}{l}\text { Understand- } \\
\text { ing }\end{array}$ & 1 & 1 & 1 & 1 & $1^{*}$ & 1 & 1 & 1 & 8 \\
\hline $\begin{array}{l}\text { Causal Am- } \\
\text { biguity }\end{array}$ & 1 & 1 & 1 & 1 & 1 & 1 & 1 & 1 & 8 \\
\hline Trust & 1 & 1 & 1 & 1 & 1 & $1 *$ & $1 *$ & 1 & 8 \\
\hline Tie Strength & 1 & $1 *$ & 1 & 1 & 1 & $1 *$ & 1 & 1 & 8 \\
\hline $\begin{array}{l}\text { Cultural } \\
\text { Similarity }\end{array}$ & 1 & 1 & 1 & 1 & 1 & 1 & 1 & 1 & 8 \\
\hline $\begin{array}{l}\text { Learning In- } \\
\text { tent }\end{array}$ & 1 & 1 & 1 & $1 *$ & $1 *$ & 1 & 1 & 1 & 8 \\
\hline $\begin{array}{l}\text { Absorptive } \\
\text { Capacity }\end{array}$ & 1 & 1 & 1 & 1 & 1 & 1 & 1 & 1 & 8 \\
\hline $\begin{array}{l}\text { Driving } \\
\text { power }\end{array}$ & 8 & 8 & 8 & 8 & 8 & 8 & 8 & 8 & \\
\hline
\end{tabular}


Due to the driving and dependence power, and therefore the reachability and intersection sets, being the same for all conditions, there is only one level present in the final digraph (Figure 2). As such, both the conical form of the reachability matrix, and the driving and dependence power diagram [48] have been excluded.

\begin{tabular}{|c|c|c|c|c|c|c|c|}
\hline $\begin{array}{c}\text { Type of } \\
\text { Knowledge }\end{array}$ & Understanding & $\begin{array}{c}\text { Causal } \\
\text { Ambiguity }\end{array}$ & Trust & $\begin{array}{c}\text { Tie } \\
\text { Strength }\end{array}$ & $\begin{array}{c}\text { Cultural } \\
\text { Similarity }\end{array}$ & $\begin{array}{c}\text { Learning } \\
\text { Intent }\end{array}$ & $\begin{array}{c}\text { Absorptive } \\
\text { Capacity }\end{array}$ \\
\hline
\end{tabular}

Fig. 2. Final ISM Diagraph

\section{FsQCA Results}

Table 3. Solutions for Knowledge Transfer Success

\begin{tabular}{|c|c|c|c|c|c|c|c|c|}
\hline & & & & Sol & & & & \\
\hline $\begin{array}{l}\text { Configura- } \\
\text { tion }\end{array}$ & 1 & 2 & 3 & 4 & 5 & 6 & 7 & 8 \\
\hline $\begin{array}{l}\text { Tacit } \\
\text { Knowledge }\end{array}$ & $\bullet$ & $\bigotimes$ & $\bullet$ & $\bullet$ & $\bullet$ & $\bullet$ & $\bullet$ & $\bullet$ \\
\hline $\begin{array}{l}\text { Explicit } \\
\text { Knowledge }\end{array}$ & $\bigotimes$ & $\bullet$ & $\bullet$ & $\bullet$ & $\otimes$ & $\bullet$ & $\bullet$ & - \\
\hline $\begin{array}{l}\text { Under- } \\
\text { standing }\end{array}$ & $\bullet$ & & $\bullet$ & $\bullet$ & $\otimes$ & $\bullet$ & $\otimes$ & $\bullet$ \\
\hline $\begin{array}{l}\text { Causal } \\
\text { Ambiguity }\end{array}$ & $\bullet$ & $\bullet$ & $\bullet$ & $\bullet$ & $\bullet$ & $\otimes$ & $\bullet$ & • \\
\hline Trust & $\bullet$ & $\bullet$ & $\bullet$ & & $\otimes$ & $\otimes$ & $\otimes$ & $\bullet$ \\
\hline $\begin{array}{l}\text { Tie } \\
\text { Strength }\end{array}$ & $\bullet$ & $\bullet$ & $\bullet$ & $\bullet$ & - & $\otimes$ & $\bullet$ & $\bullet$ \\
\hline $\begin{array}{l}\text { Cultural } \\
\text { Similarity }\end{array}$ & $\otimes$ & $\otimes$ & 0 & 0 & $\bigotimes$ & $\otimes$ & 0 & • \\
\hline $\begin{array}{l}\text { Learning } \\
\text { Intent }\end{array}$ & $\bullet$ & $\bullet$ & 0 & 0 & $\bigotimes$ & • & 0 & $\otimes$ \\
\hline $\begin{array}{l}\text { Absorptive } \\
\text { Capacity }\end{array}$ & & $\bullet$ & & $\bullet$ & $\otimes$ & $\bullet$ & $\otimes$ & $\bullet$ \\
\hline Consistency & 0.88 & 0.96 & 0.89 & 0.87 & 0.96 & 0.94 & 0.88 & 0.83 \\
\hline $\begin{array}{l}\text { Raw Cover- } \\
\text { age }\end{array}$ & 0.16 & 0.17 & 0.27 & 0.23 & 0.09 & 0.10 & 0.10 & 0.12 \\
\hline $\begin{array}{l}\text { Unique Cov- } \\
\text { erage }\end{array}$ & 0.10 & 0.11 & 0.08 & 0.03 & 0.05 & 0.03 & 0.03 & 0.05 \\
\hline \multicolumn{6}{|c|}{ Overall solution coverage } & \multicolumn{3}{|l|}{0.68} \\
\hline \multicolumn{6}{|c|}{ Overall solution consistency } & \multicolumn{3}{|l|}{0.93} \\
\hline
\end{tabular}


Eight solutions are displayed for knowledge transfer success (Table 4). Large circles denote the presence of a core condition, indicating a strong causal relationship with the outcome, and small circles signify the presence of a peripheral condition, which exhibit weaker relationships with the outcome [32]. Circles with crosses indicate condition absence: blank spaces represent redundancy.

The solutions can be grouped according to their core and peripheral conditions. Solutions one and five display the absence of Explicit Knowledge as a core condition. However, while the absence of Cultural Similarity and Learning Intent are core conditions within solution five, Learning Intent is present within solution one. Solutions three, four and seven display the core causal configuration Cultfz*Learnfz. They differ on the redundancy of Trust within solution four, redundancy of Absorptive Capacity within solution three, and the absence of Understanding, Trust, and Absorptive Capacity within solution seven. Solutions two, six, and eight are unique.

The overall solution coverage score of 0.68 indicates that the solutions explicate a substantial proportion of the outcome. Overall consistency is high at 0.93 and demonstrates a highly significant subset relationship [30].

\section{Discussion}

Both the ISM and fsQCA results retain significant implications for knowledge transfer success. In response to the first research question of this study, the application of ISM within the first phase of analysis highlighted that no condition possessed greater prominence. Conditions for knowledge transfer are highly co-dependent. To further investigate the conditions, the fsQCA findings reveal eight distinct solutions for success, assisting both theoretical and practical endeavors in terms of increasing understanding of how knowledge is transferred successfully. In terms of the second research question, fsQCA confirmed that knowledge transfer success derives from multiple solutions. The fsQCA findings reflect equifinality, displaying eight distinct solutions: additionally, no configuration met the consistency threshold when analyzed against the absence of the outcome. The findings are therefore causally asymmetrical - the configurations for knowledge transfer success are distinct from those which contribute to its absence.

\subsection{Theoretical implications}

This study complements and extends current research by presenting an alternative perspective of how knowledge transfer conditions combine. Previous studies have categorized conditions according to their characteristics, and utilized fsQCA to identify configurations for innovation-related outcomes $[4-5,33]$. This research provides empirical evidence for how different combinations of organisational, relationship and knowledge-related conditions are not only mutually inclusive, but causally significant for the outcome. The results of this research additionally verify extant studies that examine determinants of knowledge transfer success [4, 15-16] whilst extending previous findings through revealing condition interrelations and their multiple effects upon the outcome, utilizing ecosystem partner perceptions as the unit of analysis. 
Additionally, this study addresses a significant research gap, through amalgamating ISM and fsQCA as analytical techniques. ISM has also been integrated with other 'fuzzy' analyses [33-35] whilst fsQCA is commonly synthesized with statistical techniques such as Structural Equation Modelling [35]. However, fsQCA and ISM are seldom combined in the same study, particularly in innovation-related contexts.

\subsection{Managerial Implications}

The research findings also possess important practical implications. Both the ISM and fsQCA results reveal the interdependent nature of the knowledge transfer conditions. Organisations should thus reflect on the presence of such conditions, and cultivate them if missing. Additionally, an awareness of the strong interrelations between all conditions should be engendered: deficits in the presence of particular conditions could be addressed through the mediating effects of other conditions. However, the significance of individual conditions should not be overlooked. The fsQCA solutions demonstrate the pertinence of specific core and peripheral conditions: these should be noted, and their importance emphasized in practice.

\subsection{Limitations and Future Research}

A number of limitations are present within this study and could be addressed through further research. The fsQCA results reveal that $32 \%$ of the outcome remains unexplained: therefore, other conditions may be responsible, and could be identified through further research. Whilst ISM and fsQCA possess particular suitability for small-N analyses, the results are still grounded upon a small sample. Further studies could alleviate this through conducting larger scale studies employing quantitative techniques. Finally, this research was conducted on a sample of respondents from European ecosystems: cross-country analyses could be conducted to assess the role of ecosystem contexts.

\section{References}

1. MIT Sloan Management Review, https://sloanreview.mit.edu/article/the-myths-andrealities-of-business-ecosystems/, last accessed 2019/06/03

2. Moore, J. F.: Predators and prey: a new ecology of competition. Harvard Business Review. 71(3), 75-86 (1993).

3. Wulf, A., Butel, L.: Knowledge sharing and collaborative relationships in business ecosystems and networks: A definition and a demarcation. Industrial Management \& Data Systems. 117(7), 1407-1425 (2017). doi: 10.1108/IMDS-09-2016-0408

4. Bacon, E., Williams, M., Davies, G.H.: Recipes for Success: Conditions for knowledge transfer across open innovation ecosystems. Paper presented at the World Open Innovation Conference, San Francisco (2018)

5. Kraus, S., Ribeiro-Soriano, D., Schüssler, M.: Fuzzy-set qualitative comparative analysis (fsQCA) in entrepreneurship and innovation research - the rise of a method. 
International Entrepreneurship and Management Journal. 14(1), 15-33 (2017). doi: $10.1007 / \mathrm{s} 11365-017-0461-8$

6. Dwivedi, Y., et al..: Driving innovation through big open linked data (BOLD): Exploring antecedents using interpretive structural modelling. Information Systems Frontiers. 19(2), 197-212 (2016). doi.org/10.1007/s10796-016-9675-5

7. Milagres, R., Burcharth, A.: Knowledge transfer in interorganizational partnerships: what do we know? Business Process Management Journal. 25(1), $27-68$ (2019). doi.10.1108/bpmj-06-2017-0175

8. Ritala, P., Kraus, S., Bouncken, R. B.: Introduction to coopetition and innovation: contemporary topics and future research opportunities. International Journal of Technology Management. 71, 1-9 (2016). doi.10.1504/ijtm.2016.077985

9. Chesbrough, H. W.: Open innovation: The new imperative for creating and profiting from technology. Harvard Business Press, Boston (2003).

10. Van Wijk, R., Jansen, J. J., Lyles, M. A.: Inter-and intra-organizational knowledge transfer: a meta-analytic review and assessment of its antecedents and consequences. Journal of Management Studies. 45(4), 830-853 (2008). doi.10.1111/j.1467-6486.2008.00771.x

11. Bogers, M.: The open innovation paradox: knowledge sharing and protection in R\&D collaborations. European Journal of Innovation Management. 14(1), 93-117 (2011). doi.10.1108/14601061111104715

12. Argote, L., Ingram, P.: Knowledge Transfer: A Basis for Competitive Advantage in Firms. Organizational Behavior and Human Decision Processes. 82(1), 150-169 (2000). doi.10.1006/obhd.2000.2893

13. Miller, K., McAdam, R., Moffett, S., Alexander, A., Puthusserry, P.: Knowledge transfer in university quadruple helix ecosystems: an absorptive capacity perspective. R\&D Management. 46(2), 383-399 (2016). doi.10.1111/radm.12182

14. de Vasconcelos Gomes, L. A., Facin, A. L. F., Salerno, M. S., Ikenami, R. K.: Unpacking the innovation ecosystem construct: Evolution, gaps and trends. Technological Forecasting and Social Change. 136, 30-48 (2018). doi.org/10.1016/j.techfore.2016.11.009

15. Al-Salti, Z., Hackney, R.: Factors impacting knowledge transfer success in information systems outsourcing. Journal of Enterprise Information Management. 24(5), 455-468 (2011). doi.10.1108/17410391111166521

16. Cummings, J. L., Teng, B. S.: Transferring R\&D knowledge: the key factors affecting knowledge transfer success. Journal of Engineering and Technology Management. 20(1-2), 39-68 (2003). doi.org/10.1016/s0923-4748(03)00004-3

17. Bogers, M., et al..: The open innovation research landscape: Established perspectives and emerging themes across different levels of analysis. Industry and Innovation. 24(1), 8-40 (2017). doi.10.1080/13662716.2016.1240068

18. Narteh, B.: Knowledge transfer in developed-developing country interfirm collaborations: a conceptual framework. Journal of Knowledge Management. 12(1), 78-91 (2008). doi.10.1108/13673270810852403

19. Simonin, B. L.: An empirical investigation of the process of knowledge transfer in international strategic alliances. Journal of International Business Studies. 35(5), 407-427 (2004) doi.10.1109/ieem.2007.4419560 
20. Lippman, S., Rumelt, R.: Uncertain Imitability: An Analysis of Interfirm Differences in Efficiency under Competition. The Bell Journal of Economics. 13, 418 (1982). doi.10.2307/3003464

21. Inkpen, A.: Learning and knowledge acquisition through international strategic alliances. Academy of Management Perspectives. 12(4), 69-80 (1998). doi.10.5465/ame.1998.1333953

22. Cohen, W., Levinthal, D.: Absorptive Capacity: A New Perspective on Learning and Innovation. Administrative Science Quarterly. 35, 128 (1990).doi.10.2307/2393553

23. Pappas, I. O.: User experience in personalized online shopping: a fuzzy-set analysis. European Journal of Marketing. 52(7/8), 1679-1703 (2018). doi:10.1108/ejm-102017-0707

24. Osgood, C. E., Suci, G. J., Tannenbaum, P. H.: The measurement of meaning. University of Illinois Press, Illinois (1957).

25. Warfield, J. N.: Intent structures. IEEE Transactions on Systems, Man, and Cybernetics. (2), 133-140 (1973). doi.10.1109/tsmc.1973.5408494

26. Alawamleh, M., Popplewell, K.: Interpretive structural modelling of risk sources in a virtual organisation. International Journal of Production Research. 49(20), 60416063 (2011). doi.10.1080/00207543.2010.519735

27. Samantra, C., Datta, S., Mahapatra, S. S., Debata, B. R.: Interpretive structural modelling of critical risk factors in software engineering project. Benchmarking: An International Journal. 23(1), 2-24 (2016). doi.10.1108/bij-07-2013-0071

28. Pfohl, H., Gallus, P., Thomas, D.: Interpretive structural modeling of supply chain risks. International Journal of Physical Distribution \& Logistics Management. 41(9), 839-859 (2011). doi.10.1108/09600031111175816

29. Pappas, I.O., Kourouthanassis, P .E., Giannakos, M.N., Chrissikopoulos, V .: Explaining online shopping behavior with fsQCA: The role of cognitive and affective perceptions. Journal of Business Research. 69, 794-803 (2016).

30. Ragin, C. C.: Set relations in social research: Evaluating their consistency and coverage. Political Analysis. 14(3), 291-310 (2006). doi.10.1093/pan/mpj019

31. Ordanini, A., Parasuraman, A., Rubera, G.: When the Recipe Is More Important Than the Ingredients. Journal of Service Research. 17(2), 134-149 (2013). doi.10.1177/1094670513513337

32. Fiss, P.: Building Better Causal Theories: A Fuzzy Set Approach to Typologies in Organization Research. Academy of Management Journal. 54(2), 393-420 (2011). doi.10.5465/amj.2011.60263120

33. Mikalef, P., Boura, M., Lekakos, G., Krogstie, J.: Big data analytics and firm performance: Findings from a mixed-method approach. Journal of Business Research. 98, 261-276 (2019). doi.org/10.1016/j.jbusres.2019.01.044

34. Khan, U., Haleem, A.: Smart organisations: modelling of enablers using an integrated ISM and fuzzy-MICMAC approach. International Journal of Intelligent Enterprise. 1(3-4), 248-269 (2012). doi.org/10.1504/ijie.2012.052556

35. Mikalef, P., Pateli, A.: Information technology-enabled dynamic capabilities and their indirect effect on competitive performance: Findings from PLS-SEM and fsQCA. Journal of Business Research. 70, 1-16 (2017). doi.org/10.1016/j.jbusres.2016.09.004 